\title{
Death OF Popular Sovereignty? Reflections ON OUR (POST) DEMOCRATIC CONDITION
}

\section{A Morte Da Soberaania Popular? ReflexÕes Sobre Nossa Condição (Pós) DEMOCRÁTICA}

AbSTRaCT: In this article I try to answer a specific question: is it possible to recover the value and determinant role of the concept of popular sovereignty, in the actual condition of contemporary democracies? Assuming that it is still possible (and desirable) to recover this ideal and regulative principle, I want to explore the conditions that are available today in order to do so. That implies, first and foremost, to critically expose the eminent dangers brought by globalization and the new neoliberal imperialism. These put into question the set of fundamental democratic aspirations of freedom, equality and social justice. Under this light, to question about the conditions of possibility for popular sovereignty means to questions about the conditions of possibility for democracy itself. We will only be capable of recuing democracy if we redefine: a) the relationship between individual and community; b) the relationship between democratic nations and non-democratic global organizations; c) the space where democracy should take place (from nation-state to local communities). This article has four moments. First, I offer a brief reading of the concept of popular sovereignty in modernity, having as main reference Rousseau. In the second moment I characterize contemporary democratic constellation in its dialogue between Bernard Manin (1997) and
RESUmo: Neste artigo procuro responder a uma questão específica: é possível recuperar o valor e papel determinante do conceito de soberania popular, na condição das democracias contemporâneas? Presumindo de que é ainda possível (e também desejável) recuperar este ideal e princípio regulador, quero explorar que condições temos à nossa disposição hoje que nos permitam fazê-lo. Isso implica, antes de mais, expor criticamente os perigos eminentes trazidos pela globalização e pelo novo imperialismo neoliberal, que põem em cheque as aspirações democráticas fundamentais de liberdade, igualdade e justiça social. Neste sentido, questionar sobre as condições de possibilidade da soberania popular significa questionar as condições de possibilidade para a própria democracia. Só conseguiremos recuperar a democracia se redefinirmos: a) a relação entre indivíduo e comunidade; b) a relação entre nações democráticas e organizações globais não-democráticas; c) o espaço onde a democracia deve acontecer (da nação-estado para comunidades locais). Assim, este artigo tem quatro momentos. Primeiro, ofereço uma leitura do conceito de soberania popular na modernidade, tendo como ponto de referência a obra de Rousseau. No segundo momento caracterizo a constelação democrática contemporânea, a partir das leituras oferecidas por

* Doutora em Ciência política pela New School for Social Research. Professora Visitante do Departamento de Filosofia da Universidade Federal de Santa Catarina - UFSC, e do Programa de Pós-Graduação em Filosofia na mesma universidade. m@ilto: nunesdacosta77@gmail.com 
Nadia Urbinati (2006). In the third moment I focus on the tension between democratic ideals and neoliberal hegemony. Finally, I look into the conditions of possibility for rescuing democracy and popular sovereignty.

KEYWORDS: democracy, globalization, neoliberalism, political equality, popular sovereignty.

\section{Popular SOVEREIGNTy IN MODERNITY}

'My purpose is to consider if, in political society, there can be any legitimate and sure principle of government, taking men as they are and law as they might be.' (ROUSSEAU, 1968, p. 49)

D ousseau starts The Social contract with these words. His 1. purpose is clear - to define the type of government capable of reflecting and respecting human nature as it is, and capable of producing laws as they should be. We will not enter here on the details about the grounds upon which Rousseau develops his conceptualization of human nature. For our purpose it is enough to consider that his main goal is to 'find a form of association which will defend the person and goods of each member with the collective force of all, and under which each individual, while uniting himself with the others, obeys no one but himself, and remains as free as before.'(ROUSSEAU, 1968, p.60)

The challenge is set in the first pages of the book: to understand how is it possible to maintain original freedom that constitutes the human being as such, transforming it in a freedom with meaning and recognition for others, therefore, transforming it in political freedom, capable of simultaneously translating the respect for principles of justice that support the political community. His strategy consists in a definition of social contract that leads to a theory of popular sovereignty (initially proposed by authors like Althusius) taken to its extreme form. This social contract requires '[the] total alienation by each associate of himself and all his rights to the whole community.' (ROUSSEAU, 1968, p.60) The idea, that can be discussed, is that individuals' total alienation is translated in the invention and conquest of political equality. This equality has a double nature: it is negative, insofar it is a product of alienation; but it is also positive, translated in the creation of a general will. The act of alienation creates this 
'artificial body', this 'common ego', with its life and will. (ROUSSEAU, 1968, p. 61) We arrive at a general will that, when playing its active role, 'is the sovereign' (ROUSSEAU, 1968, p. 62). Sovereignty, therefore, is nothing more than 'the exercise of the general will' (ROUSSEAU, 1968, p. 69), and 'by the fact that it is, it is always what it should be'. (ROUSSEAU, 1968, p. 63) From here follows that sovereignty is inalienable, it doesn't allow for representation ${ }^{1}$, and it is indivisible. There is only one bearer of sovereignty, which is the people; there is only one possible form of government: the democratic. The sovereign people appears not as someone specific (which would violate the equality that can only be achieved through its general character), but as 'all'. In what ways, then, does the people translate its sovereignty? In the legislative function, i.e., in the creation of laws, since the law 'unites the universality of the will with the universality within the legislative domain [...]'. Laws are acts of the general will, they are constitutive acts of the political community.

But how are laws implemented? It is impossible for the sovereign to fully act in all political spheres; therefore, while the sovereign is the supreme authority of the state and the prince only its deputy, it is necessary to create a political body capable of dealing with facts and concrete men. Government, then, '[is] an intermediary body established between the subjects and the sovereign for their mutual communication, a body charged with the execution of the laws and the maintenance of freedom, both civil and political.' (ROUSSEAU, 1968, p. 102)

Here we get to a problem. The sovereign is sovereign insofar it remains 'universal', i.e., insofar it envisions the common good and translates this concern in laws, which by definition are general. While the general will determines what constitutes the just and fair and how justice should be administrated-determining which actions should be punished and rewarded - it cannot judge individuals. This limit conditions its own power, and we arrive at the visible tension in Rousseau: if the sovereign only deals with generality, and the prince only applies the law to particulars, it is also true that the sovereign can put aside the prince when he does not exercise his power in adequate and proper manner. But which conditions does sovereignty has that allows it to make such a judgment and determine what constitutes, or not, a good execution of the laws? If as our starting-point the sovereign cannot think about particulars, where should we look for the criteria 
that allow him to politically and morally judge the accurateness of laws' interpretation and application? Indeed, Rousseau recognizes that '[...] if in the end it comes about that the prince has a particular will more active than that of the sovereign, and if, to enforce obedience to this particular will, he uses the public force which is in his hands, with the result that there are, so to speak, two sovereigns, one de jure and the other de facto, then the social bond vanishes at once and the body politic is dissolved.' (ROUSSEAU, 1968, p.106)

It is crucial to answer this question; otherwise it is impossible to keep the system of 'checks and balances' that Rousseau proposes. (SIMPSON, 2006, p. 51) One can overcome this dilemma by returning to the sovereign, as exercise of the general will, within the realm of citizens' assemblies. (ROUSSEAU, 1968, p.147) If one accepts that these assemblies have the function of maintaining the social pact and of questioning measures or proposals that condition or put into question this same pact, it becomes clear that here we find the necessary institutional space that would allow the revision of social pact's conditions and the successive restoring of this pact. Today, these conditions are perceived as threats to the mainstream democratic model, which grounds itself mainly in representative institutions.

But how can we justify the shift from a Rousseaudian model of democracy, founded on participatory practices, to the actual model of contemporary democracies, which are mainly representative?

\section{II.CONTEMPORARY DEMOCRATIC CONSTELLATION}

Rousseau acknowledged that 'in the strict sense of the term, there has never been a true democracy, and there never will be [because] it is contrary to the natural order that the greater number should govern and the smaller number be governed.' (ROUSSEAU, 1968 , p. 112) We only have mix government, since, 'strictly speaking, no government of a simple form exists'. (ROUSSEAU, 1968, p.122) However, it was clear his position that representation would endanger and kill any concept (and practice) of popular sovereignty. Representation would violate the three principles of popular sovereignty: unity (as 'the people'), inclusion and reciprocity. Representation would transfer sovereignty to the 'few'.

Bernard Manin in The Origins of Representative Government 
(2005) explains why this transference from 'popular sovereignty' to representative institutions happened. He goes back to the American and French revolutions to show that during this time of creating a new constitution and defining a new form of government, there was absolutely no regard for the traditional democratic methods - such as lottery - and there was a general consensus that election was the method of selection for government. In order to fabricate this consensus, one identifies a shift in the discourse about what constitutes a legitimate form of government as well as the source of political obligation. From the moment 'consent' appears as political category to justify political obligation, the question of lottery versus election appears under a different light: with lottery, there is never a question of consent, it is a question of political equality affirmed as capacity that each individual has of governing and speaking in the public sphere. With election, on the other hand, the citizen starts to be seen as source of political legitimacy but not as political agent per se. The citizen can consent to be represented by the 'few', assuming that these 'few' match a set of criteria and conditions of the hypothetical social pact, but he is not, himself, an obvious candidate for public offices. Manin's goal is to show that the logical apparatus and the institutional instantiations of representative government, implemented during the XVIII century, remain largely unchanged. Therefore, even today, we are permanently challenged in defining 'democracy', because democracy appears as a combination of democratic and aristocratic elements, or as Aristotle would put it, as a mix constitution.

While Manin's reading denounce a suspicious attitude vis-à-vis the democratic nature of democracies, Urbinati, on the other hand, presents a more optimistic - at least a more open - approach to representation. For Urbinati (2006) representation can never be reduced to a mere act of authorization or contract. Representation becomes 'democratic' representation insofar it is simultaneously constituted by the particular and the general. Under this light, representation must be seen as 'original form of political participation' (URBINATI, 2006, p.133). Given that representation is not a contract, it can be defined as relationship supported by 'ideological sympathy and communication', i.e., 'in democratic politics, representation does not mean "acting in the place of somebody", but being in a political relation of sympathetic similarity or communication with those in the place of whom the representatives act in the legislature.' (URBINATI, 2006, p.133) 
Representation appears as unifying process, not as translation of a previous unity. It also assumes a horizon of plurality and difference, from which all positions acquire meaning and political significance. Urbinati expands the concept of representation, linking traditional representative institutions to the crucial and vital importance of informal politics where the representative relationship also happens. Therefore, representation in Urbinati encompasses both participatory and deliberative dimensions insofar it is supported by the idea of direct and open channels of communication between representatives and represented, between state institutions and social practices. Sovereignty, for Urbinati, ought to be redefined under the light brought by this conceptual expansion; from the Rousseaudian 'general will 'we would get to a more mutable and versatile conception of sovereignty, understood as unifying process with pluralism as its background. (URBINATI, 2006, p.134) For Urbinati, the concept of sovereignty proposed by Rousseau has to be expanded and transformed encompassing the vital importance of political judgment. The legitimacy of democracy depends on the judgment made by the represented actors. (AVRITZER, 2012, p.1)

In more recent texts, both Manin and Urbinati seem slightly more disenchanted about the present and future of democratic politics. Political parties are no longer capable of translating people's interests and claims and it is becoming increasingly more difficult to sustain the previous reading of the more expanded concept of representation where participation, deliberation and representation go hand-in-hand. Adding to this there is an increase of economic (and therefore, political) inequality, which forces us to ask what went wrong (or more wrong than expected). Urbinati clearly states that contemporary democracies are at stake due to privatization and concentration of wealth within the sphere of public opinion's formation as well as due to the growth of demagogic inputs in the (ever-going) political consensus. Even the internet that was viewed by many as possible alternative and complementary space for political discourse and action is mainly being used as means for reinforcement of already established social practices - of consumerism, of creating 'private' spheres, etc. But adding to this we could identify a privatization of the public sphere (through the imperial power of transnational corporations that owe spaces of communication and means for the 'freedom of expression'), along with a progressive eradication of what would constitute the 'private' sphere 
(since even the most private things of human beings are being publicly exposed through the internet and social media), and these elements all together make us question what remains common to all of us.

To identify what is common is to identify what is intrinsically political in nature. Politics is about common life, it is a realm where individuals leave their private dimensions and appear in a public space as citizens, to encounter others, as equals. If these two elements I mentioned - privatization of public sphere and publicization of private sphere - distort the image individuals make of themselves, by limiting them to the role of spectators of a great world scenario, it means that individuals are led to forget their condition as political beings. And as Arendt would say, following Aristotle's path, the human being is a political being, a being that can act, and not merely reproduce behaviors and thoughts or work in order to survive. One could say, in a preliminary tone, that critique is crucial to recover our human condition as political beings. We will get to this on the last part of this paper. For now, we still need to characterize our current state of affairs, and more precisely, the relationship between democracy and neoliberalism, that is at the basis of our present socio-political constellation.

\section{III.DEMOCRACY VERSUS NEOLIBERALISM}

Rousseau's creation of the 'general will' is the foundation of one of the most important concepts of modernity until today, namely, the concept of autonomy, which was latter developed and systematized by Kant and furnished the ground for the paradigm of liberal-democracies. The act of self-legislation plays the key role in defining autonomy, which is at the foundation of the concept of popular sovereignty. The subject gives himself the law that he will follow - a universal law, recognized as such by every other human being. This act of selflegislation - and the reciprocity and recognition it entails - happens within a political community, defined by the regulative principle of equality. Equality, in Rousseau, is revealing of the truly democratic nature of democracy. Equality is not a claim for recognition of identical talents, gifts, skills or strengths; equality is political equality, i.e., it is the condition that everyone shares with everybody else where each is part of a political body and as such, each individual has the right (and duty) to participate in the construction and maintenance of it. However, 
one is not born equal; one becomes equal to others.

One becomes political equal when one has already met some economic requirements, such as having property. Economic independence is a condition for political equality because one can only have the mental and physical conditions to think and reflect about the res publica when one is no longer consumed by the realm of needs, the realm of mere survival. Arendt was clear on this matter. Politics is the 18 realm of action, which has nothing or little thing to do with the realm of necessity (of nature) and the realm of labor. When Rousseau argued for some economic independence, he was not arguing that all individuals should have the same; indeed, how wealth was distributed was not his concern. More than economic independence, however, Rousseau wanted to underline the nature (and necessity) of human interdependence, showing how individuals must cooperate with each other in order to sustain the harmony within the republic. Common good, therefore, converges with private good. Private interests are best defended and promoted when common interests are promoted.

Political equality is one of the core values of democracy. Even if there are many different contours each specific democratic project may take, without political equality a system cannot claim to be democratic.

Rousseau knew that this political equality required that other conditions had to be fulfilled. Even Robert Dahl (2006) argues that political equality faces serious challenges today, mainly due to the pernicious involvement of economics and finance in the political sphere. On the other hand, we see that political equality - as foundational principle and regulative ideal of democracy - is at stake today, not only within specific democratic nations, but also at a global level. Once we turn to the question of why is political equality at stake, we are immediately confronted with the tension between the political and social aspirations of democracy and the global rules of neoliberalism.

Neoliberalism as economic (and political) theory was developed during the 1950's and 1960's by Hayek, Friedman, and others, but gained visibility and power as alternative ideology during the 1970's. In a time marked by another crisis of capitalism, when Keynesian model was no longer producing expected results and the accumulation of capital became compromised, neoliberalism, which was until then a proposal of a minority group at margins of the mainstream political and 
economic thought, had the opportunity of making the difference and jumping out to the center of capitalism's recovery. Thatcher and Reagan were two of the fierce defenders of neoliberal theory. Of course, as Harvey points out (2011a an 2011b) neoliberalism as theory is one thing, neoliberalization, is another. Neoliberalism's strategy consists in the disciplinary restructuring of labor forces, readjustment of public debt in countries, flexibilization of labor markets, opening of markets in the name of competitiveness, privatization of public goods such as water, energy, etc. - de-regulamentation, and constant reinvention of forms through which 'primitive accumulation' can reinvent itself. Neoliberal ideology progressively conquered the globe.

Neoliberalism is incompatible with democracy and in ultimate instance with politics. Even if Harvey tells us that neoliberalism is part of a larger political project, aimed at strengthening the power of elites (HARVEY, 2011a, 2011b), we should only understand the world 'political' in this context as standing for a specific strategy of further accumulation using the 'political' space and the 'political' appearances to make the life of the 'few' easier and to be considered as legitimate by those who are increasingly usurped, exploited and reduced to misery. The irony with neoliberalism is that it actually never accomplished what its purpose was, namely, to reestablish levels of economic growth, even the considered as necessarily minimum for the maintenance of the capitalist system ( $3 \%$ of GPD). Nonetheless, this fact seems irrelevant by those who are forced to accept 'adjustment programs' led by IMF, World Bank, European Bank and European Commission. Recent European history is a living proof of this. Greece, Portugal, Ireland, but also other countries that are hunted by IMF predictions and expectations, force their populations into a contract that no one accepts of endorses. Under this light, we should ask: what are the implications of neoliberalism for democracies, in particular, and politics in general?

Authors like Benjamin Barber (2008) argue that if sovereignty is a necessary precondition for democracy (which you cannot have without a state), when sovereignty is at stake, so democracy is stake. Clearly, from the moment assertions like 'there is no such thing as society' (Margaret Thatcher) or 'there is no such thing as public interest' (Reagan) are absorbed and interiorized by individuals, Thatcher's prediction that neoliberalism had to transform the soul, is realized. With this, something very wrong starts to happen. Not only 
are citizens progressively transformed and converted into passive consumers, but also nations become pieces of a large global game of which they have absolutely no control. They simply must play by the rules, defined by the tiny $1 \%$ of the world. Let us step back for a moment.

We started this section by showing that political equality is one of the core values of democracy. Political equality means equal right to vote, but also equal right to participate in the making of the agenda and to influence public policy. Popular sovereignty must be understood in $\stackrel{\sim}{i}$ this sense: when individuals feel and know that their opinion, their $\stackrel{1}{\ddagger}$ position, their interests, count for something; when individuals as i citizens, as political beings, feel represented by their representatives, feel that the judgment and decision-making of their representatives stand for the common good and for the public interest. Political equality fosters political freedom, i.e., the capacity for action in politics, through participation in several levels of government.

One of the premises of neoliberalism is freedom. But freedom here is to be understood essentially in a negative sense, as freedom as non-interference from the state in individuals' action. This noninterference grants the space for personal initiative, for competition, for ambition and drive. But what this portray erases from the picture of politics is the common aspect of life and of living. Neoliberalism offers a portray where society is to be understood (and reduced to) as individuals considered as atoms, separated from each other, with no special bound or social ties. The radical individualism promoted through the rhetoric of freedom, accomplishes the ultimate goal: the absorption of politics into the realm of economics and finance; the death of politics and the rise of a new human order, where freedom is nothing but a nice word, one which unfortunately only the few can taste its meaning.

Countries that go through the structural adjustments programs of IFM lose, as a matter of fact, their sovereignty. The democratic procedures remain - regular elections, representative institutions - but the channels of communication between representatives and represented are now closed; if not closed they are at least restricted to a bare minimum of creating political results. One just needs to think of European countries to see this displacement of national sovereignty (through popular participation and/ or popular consent) to a new transnational or global sovereignty led by financial institutions. 
Approximately $70 \%$ of political decision-making that impacts every European country happens at the level of the European parliament. That means that from the $100 \%$ that national citizens ought to deliberate, participate or contribute in the political process, only $30 \%$ or less are available for people's reflection and input. Even these 30\% formally available for actual politics become hostages of Troika, that now force governments to implement their policies' suggestions. Popular sovereignty? Apparently not. As Barber says

"Citizens become subject to laws they did not really participate in making; they become the passive constitutions of representatives who, far from reconstituting the citizens' aims and interests, usurp their civic functions and deflect their civic energies." (BARBER, 2003, 147)

Given such a scenario, where globalization and capital's enhancement through neoliberal imperalism force us to a childish and passive position of mere consumerism, where the public good is subverted and popular sovereignty privatized by the hands of the elite that escape from any possible democratic control, what tools do we have available today to rescue democracy and recover popular sovereignty?

\section{RESCUING DEMOCRACY - WHERE IS THE FUTURE OF POPULAR SOVEREIGNTY?}

In the previous sections I offered a reading of the foundations of the concept of popular sovereignty - based on a general will that exercises itself; I tried to show how the shift from a participatory model of democracy to a representative model opened the path for a new geopolitical configuration, where progressively popular sovereignty became privatized by the few. These few, however, under neoliberal imperialism and the perpetuation of the logic of capital's accumulation, escape any form of democratic accountability. Also, they have no pretension or interest to represent the 'many'. The expansion of neoliberalism at global scale and its hegemonic consolidation led to an erosion of the public spaces where possible alternative ideologies could emerge. The privatization of the public, which happens in most of democratic nations (despite the internet) contributes to the 
reinforcement of a global society marked by great inequalities and structural social and political gaps, that endanger the surviving existing public spaces, necessary for common action, dialogue, reciprocity and deliberation among citizens about the common good. The trend of globalization brought an erosion of the concept of national sovereignty, insofar while states remain officially sovereigns they are increasingly more dependent on others. Issues became global and must be addressed at global level, in a concerted action among nations. However, the fact that the scope of national sovereignty was adjusted and restructured while formally maintaining itself - does not assure, by itself, the existence of popular sovereignty. As I tried to show, the existence of popular sovereignty can be contested on several grounds, of which Europe is but one example.

Where is the future of popular sovereignty? By asking 'where' I am already suggesting that our problem today is not to define popular sovereignty - 'what' it is - because Rousseau's account (reflected in most of participatory models of democracy) remains valid and pertinent. I ask 'where' because I am convinced that to address the contemporary democratic challenge implies rethinking 'where' democracy ought to happen.

It doesn't seem like there is a way back to national sovereignties as unique and autonomous centers of power and will; the nation-state has been transformed with globalization. While we still need states and central governments to function, it doesn't seem that the nation per se can solve our problems. Briefly, we cannot wait for the nation-state to rethink the democratic representative relationship, in order to rescue citizens' voice, will and power. There are too many external pressures and financial interests in game.

Recovering popular sovereignty implies recovering the concept (and practices) of citizenship. Given that there are still no global citizens, where should we look for alternatives? If a citizen is a member of a political community, and if the larger political community (the nation) is going through some kind of metamorphosis (in its 'democratic' nature), we must recover the citizen through his/her local community. This is the basic premise upon which Barber (2013) develops his hypothesis 'if mayors ruled the world'.

We will not enter here the details of Barber's argument; for our purpose it is worth noting that Barber is one author among others who 
stresses the vital need of betting in social and political innovation. Shifting from the nation-state to the city as ideal and real political space where change can happen allows us to create a more realistic and manageable approach to contemporary challenges. Since 1983 when Barber wrote Strong Democracy, that the author shows how globalization brings

"[...] an internationalization of goods, markets, crime, disease, poverty, capital, drugs, weapons, and terrorism; [globalization] describes the malevolent and anarchic side of sovereignty's weakening. But it does not describe anything like the internationalizing of civic or of political institutions, because this has yet to occur. Global relations are ruled by anarchy (no global democratic governance institutions at all) or by private tyranny (market forces manipulated by global corporate monopolies and less than-democratic transnational institutions like the IMF and the WTO) and not by any innovative forms of benevolent or constructive interdependence grounded in transnational forms of citizenship or of civil society." (BARBER, 2003, p. xi)

Barber's argument in this book was to show how a strong democracy depends on a strong feeling of citizenship:

"Democracy can survive only as strong democracy, secured not by great leaders but by competent, responsible citizens. Effective dictatorships require great leaders. Effective democracies require great citizens. We are free only as we are citizens, and our liberty and our equality are only as durable as our citizenship. We may be born free, but we die free only when we work at it in the interval between." (BARBER, 2003, preface to the 1990 edition, p. xxix)

Given the actual context of individuals' political indifference with a visible increase of political abstention and lack of motivation for citizens to participate - the restoration of democracy's credibility and legitimacy depends on rescuing spaces for popular sovereignty is a condition. If we accept Barber's premises that representation is incompatible with freedom, equality and social justice ${ }^{2}$, we must look for spaces that can revitalize the sense of citizenship, which is necessarily linked with an active conceptualization of politics.

Brazil is a paradigmatic case that has implemented several democratic innovative institutions for the past 30 years, providing us with fertile theoretical and practical ground to overcome the crisis of 
representation (generally perceived through the angle of aggregation of preferences). Participatory budgeting, policy councils and national conferences are some examples of participatory institutions, which also include deliberative dimensions. According to Avritzer, these spaces of civil society have as their foundation the idea of 'non-electoral authorization'. (AVRITZER, 2012, p.16) Groups, civil associations, and individual citizens are mobilized: a) to define the set of priorities for budgetary allocation at city level (in the case of participatory budgeting); b) to transform the decision-making process in different policy fields by the outcomes brought by the deliberative process between state and civil society actors (in the case of policy councils); c) to discuss different topics and arrive at a set of recommendations to the government, at city, state and national level (in the case of national conferences). These three initiatives - regardless of the different level of impact each may have in quantitative or qualitative terms introduce a new element in the representative relationship, '[...] generating new patterns of relation between the law-making body and the citizenry.' (AVRITZER, 2012, p.14) The expansion of spaces where citizens can constitute themselves as political beings generates a new dynamics in politics.

Politics happens within the city, within the neighborhoods; first and foremost it is an activity of people who are concerned with the 'same' space (physical and virtual), who find in their space their conditions of existence and development. Therefore, citizenship must also be redefined and considered above all as 'a function of what we do' (BARBER, 2003, p.226). Popular sovereignty can be recovered as exercise of the general will when people assemble, deliberate, reflect, judge and decide on common matters, supported by empathy, dialogue and reciprocity.

I conclude with Barber's quote, when he says that in a strong democratic community "[...] the individual members are transformed, through their participation in common seeing and common work, into citizens. Citizens are autonomous persons whom participation endows with a capacity for common vision." (BARBER, 2003, p. 232)

\section{REFERENCES}

AVRITZER, Leonardo, "Democracy beyond aggregation: the 
participatory dimension of public deliberation" in Journal of Public Deliberation, vol. 8, iss.2, article 10, 2012. Available at: http://www.publicdeliberation.net/jpd/vol8/iss2/art10

AVRITZER, Leonardo, Participatory Institutions in Democratic Brazil, John Hopkins University Press, Baltimore, 2009.

BARBER, Benjamin, "Shrunken Sovereign: Consumerism, Globalization, and American Emptiness" in World Affairs, Spring 2008, available at http://www.worldaffairsjournal.org/article/shrunken-sovereignconsumerism-globalization-and-american-emptiness (accessed in July 5, 2014)

BARBER, Benjamin, If Mayors ruled the world, Yale University Press, 2013.

BARBER, Benjamin, Strong Democracy, University of California Press, 2003.

HARVEY, David, A Brief history of neoliberalism, Oxford University Press, Nova Iorque, 2011.

MANIN, Bernard, The Principles of Representative Government. Cambridge: Cambridge University Press, 1997

NUNES DA COSTA, Marta, "How participatory budgeting changes the meanings and practices of citizenship" in Ethica International Journal for Moral Philosophy, vol. 12, n.2, pp. 302- 320, 2013(a)

NUNES DA COSTA, Marta, Modelos Democráticos, Arraes Editores, Belo Horizonte, 2013(b)

ROUSSEAU, J.J., The Social Contract, Penguin Books, London, 1968.

SIMPSON, Matthew, 'A Paradox of Sovereignty in Rousseau's Social Contract' in Journal of Moral Philosophy, vo.3 (1), 2006, pp.4556

URBINATI, Nadia, Representative Democracy, Chicago University Press, Chicago, 2006.

\section{Notas}

1 "[...] power may be delegated, but the will cannot be." (ROUSSEAU, 1968, p. 69)

2 "Representation is incompatible with freedom because it delegates and thus alienates political will at the cost of genuine self-government and 
autonomy. [...] Freedom and citizenship are correlates; each sustains and gives life to the other. Men and women who are not directly responsible through common deliberation, common decision, and common action for the policies that determine their common lives are not really free at all, however much they enjoy security, private rights, and freedom from interference.

Representation is incompatible with equality, [... because $]$ in the absence of community, equalities a fiction that not merely divides as easily as it unites but that raises the specter of a mass society made up of indistinguishable consumer clones.

Representation, finally, is incompatible with social justice because it encroaches on the personal autonomy and self-sufficiency that every political order demands, because it impairs the community's ability to function as a regulating instrument of justice, and because it precludes the evolution of a participating public in which the idea of justice might take root." (BARBER, 2003, p. 146) 